\title{
Gene expression of the insulin-like growth factors and their receptors in human neuroblastoma cell lines
}

\author{
D.M. Martin ${ }^{\text {a }}$, D. Yee ${ }^{\text {c }}$, R.O. Carlson ${ }^{b}$ and E.L. Feldman ${ }^{a}$ \\ ${ }^{a}$ Department of Neurology and the Neuroscience Program, ${ }^{b}$ The Mental Health Research Institute, University of Michigan, Ann Arbor, MI 48109 \\ (USA) and ${ }^{c}$ Department of Medicine, Division of Oncology, University of Texas Health Science Center, San Antonio, TX 78284 (USA)
}

(Accepted 5 May 1992)

Key words: Insulin-like growth factor I; Insulin-like growth factor II; Type I IGF receptor; Type II IGF receptor; Neuroblastoma; mRNA

Insulin-like growth factors (IGF) I and II are polypeptides with both growth-promoting and insulin-like metabolic effects. The developmentally specific expression of IGF I and II in the nervous system implies a role for these growth factors in neuronal growth and differentiation. In the present study, we analyzed IGF and IGF receptor mRNA transcripts from two related human neuroblastoma cell lines, SH-SY5Y and SK-N-SH. These cell lines provide a good in vitro model of neuronal development. Northern analysis of total RNA from each cell line revealed three IGF II mRNA transcripts $(6.0,4.8$, and $1.8 \mathrm{~kb})$, and one mRNA transcript each for the type I (11.0 kb) and type II (9.4 kb) IGF receptors. The size distribution of these multiple transcripts is similar to that found during normal human fetal development. These results establish both cell lines as good in vitro models for investigating the mechanisms which underly IGF gene expression during nervous system development.

\section{INTRODUCTION}

Insulin-like growth factors I and II (IGF I and IGF II) belong to a family of polypeptides with growth promoting and insulin-like metabolic activity ${ }^{10,33}$. Gene expression of IGF I and II is differentially regulated during development ${ }^{8}$. IGF mRNAs are present in a wide variety of size classes, depending on the developmental stage and tissue source of the transcripts. In human fetal brain, the primary IGF I mRNA species are 4.4 and $7.5 \mathrm{~kb}^{31}$. In adult human brain, expression of IGF I mRNA is negligible or absent ${ }^{8,33}$, however, a 7.0-7.5 kb IGF I mRNA is present in adult rat brain". Transcription of the IGF II gene is initiated at one of four promotor sites, leading to mRNAs with similar coding but different $5^{\prime}$ untranslated regions ${ }^{13}$. A $6.0 \mathrm{~kb}$ IGF II mRNA is abundantly expressed in fetal tissues with lesser expression in the adult, where a $4.8 \mathrm{~kb}$ mRNA likely represents the major adult IGF II transcript $^{5,6,11,33}$.

As an initial approach toward understanding the regulation of developmentally specific IGF mRNA transcripts in the nervous system, we characterized the different IGF mRNA transcripts in two human neuroblastoma cell lines, SH-SY5Y and its parent line, SK-N$\mathrm{SH}$. These cell lines were chosen as neuronal models of IGF gene regulation and function for two reasons. First, both cell lines undergo phenotypic changes from mitogenically active to differentiated neurons, thereby providing in vitro models of normal neuronal development ${ }^{23,24}$. Secondly, these phenotypic changes can be affected by IGFs ${ }^{12,26,27,28}$. We therefore speculated that mitogenically active SH-SY5Y and SK-N-SH cells would have the same IGF and IGF receptor transcripts as fetal neuronal tissue.

In the current study, we have characterized all IGF and IGF receptor mRNA transcripts present in actively dividing SH-SY5Y and SK-N-SH cells. We report that the distribution of these transcript sizes in mitogenic cells is similar to that found in the developing nervous system. Our results in mitogenic neurons can serve as a basis for future comparisons between the IGF and IGF receptor mRNA transcripts present in dividing and differentiated neuronal phenotypes. 


\section{MATERIALS AND METHODS}

\section{Materials}

Dulbecco's modified Eagle's medium (DMEM) and fetal bovine serum (FBS) were purchased from Grand Island Biological Co. (Grand Island, NY). Bovine calf serum (CS) was obtained from Hyclone Labs (Logan, UT). Tissue culture supplies were obtained from Costar (Cambridge, MA) and Corning Glass Works (Corning, NY). All molecular biology grade reagents were from Sigma (St. Louis, MO). Restriction endonucleases were purchased from Bethesda Research Laboratories (Gaithersburg, MD). All other chemicals were of reagent grade from Baker Chemical Co. (Phillipsburg, NJ) or Fisher Scientific (Fairhaven, NJ)

\section{Cell culture}

Human SH-SY5Y and SK-N-SH cells were kindly provided by Dr. Stephen Fisher, University of Michigan Medical Center. Cells were maintained in plastic tissue culture flasks in DMEM supplemented with $10 \%$ CS for SH-SY5Y and $10 \%$ FBS for SK-N-SH. Cells were maintained at $37^{\circ} \mathrm{C}$ in a humidified atmosphere of $10 \%$ $\mathrm{CO}_{2}$.

\section{cDNA probes}

Dr. Peter S. Rotwein (Washington University School of Medicine. St. Louis, MO) provided the human IGF IA $\mathrm{CDNA}^{30}$. An 818-base pair (bp) sequence of the IGF IA cDNA encoding exons 1, 2, 3 and 5 was obtained by digestion of pBlueScript KS (Stratagene, La Jolla, CA) with Eco RI. Dr. Graeme I. Bell (Howard Hughes Institute, Chicago, IL) supplied the cDNA for human IGF $\mathrm{II}^{\mathrm{I}}$. Digestion of pGEM4 (Promega, Madison, WI) with $P_{s t}$ I yielded an 854 bp region of IGF II cDNA encoding exons 7, 8, and part of 9 (bases 1-854). This cDNA was used in Northern analysis and RNase protection experiments. The type I IGF receptor $\mathrm{cDNA}^{36}$ was a gift of Dr. Axel Ullrich (Max Planck Institute, Martinsreid, Germany). A 1247 bp insert (bases 1490-2737) encoding the type I IGF receptor a and b chains was obtained by digestion of pGEM4 with Eco RI and Hind III. Dr. William S. Sly (St. Louis University Medical Center, St. Louis, MO) provided the type II IGF receptor $\mathrm{CDNA}^{20}$. The complete 9.1 kb type II IGF receptor cDNA was obtained by digestion of pGEM2 with $S a l$ I. All cDNAs were labelled with $\left[{ }^{32} \mathrm{P}\right] \mathrm{dCTP}$ by random priming (Amersham, UK) for use in hybridization reactions.

\section{Northern analysis}

Northern analysis was performed as previously described ${ }^{16}$. Briefly, total cellular RNA was isolated from SH-SY5Y and SK-N-SH cells using guanidinium thiocyanate-phenol extraction ${ }^{3}$. RNA samples $(20 \mu \mathrm{g})$ and $5 \mu \mathrm{g} 0.24-9.5 \mathrm{~kb}$ RNA ladder (Bethesda Research Laboratories) were electrophoresed in denaturing gels containing $1 \%$ agarose, 2.2 M formaldehyde, 0.02 M MOPS (3-[ $N$-morpholino] propane-sulfonic acid), $1 \mathrm{mM}$ EDTA, and $5 \mathrm{mM}$ sodium acetate. Nytran membranes (Schleicher and Schuell, Keene, NH) were hybridized with high specific activity $\left(2-90 \times 10^{7} \mathrm{cpm} / \mu \mathrm{g}\right) \mathrm{cDNA}$ probes for $12-16 \mathrm{~h}$ at $42^{\circ} \mathrm{C}$. Membranes were exposed to autoradiographic film (Eastman Kodak Co., NY) in the presence of intensifying screens at $-70^{\circ} \mathrm{C}$ for $1-7$ days.

\section{RNase protection assay}

RNase protection was performed as previously described ${ }^{16}$. RNA samples $(10-50 \mu \mathrm{g})$ were hybridized overnight at $50^{\circ} \mathrm{C}$ with $5 \times 10^{4}$ cpm IGF II riboprobe, then digested with $40 \mu \mathrm{g} / \mathrm{ml}$ RNase A (Sigma). Samples were extracted with phenol, precipitated and resuspended in $5 \mu \mathrm{l}$ of $80 \%$ formamide loading buffer, then electrophoresed on $6 \%$ polyacrylamide, $8 \mathrm{M}$ urea sequencing gels. Gels were then dried and exposed to autoradiographic film using an intensifying screen at $-70^{\circ} \mathrm{C}$ for $1-3$ days.

\section{RESULTS}

\section{IGF gene expression}

Using Northern analysis of total RNA isolated from SH-SY5Y and SK-N-SH cell lines, we found that an 854 bp IGF II cDNA hybridized with $1.8,4.8$ and 6.0 kb RNA transcripts from both cell lines (Fig. 1A,B). By

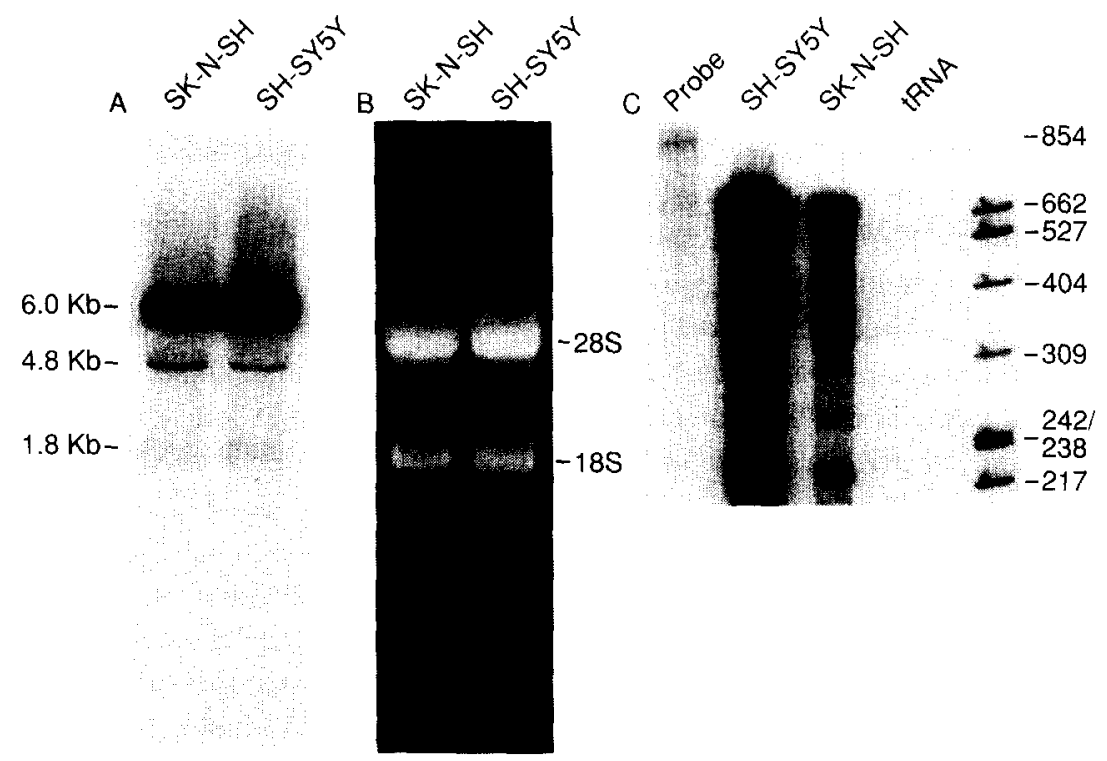

Fig. 1. Northern analysis of IGF II in cultured human neuroblastoma cells. A: Northern blot of $20 \mu \mathrm{g}$ total RNA from SK-N-SH and SH-SY5Y neuroblastoma cells. Three RNA transcripts were detected: $6.0,4.8$, and $1.8 \mathrm{~kb}$. Radiograph exposed 5 days. B: photograph of ethidium bromide-stained gel corresponding to the membrane used in A, showing $28 \mathrm{~S}(5.0 \mathrm{~kb})$ and $18 \mathrm{~S}(1.8 \mathrm{~kb}) \mathrm{rRNA}$ bands. C: IGF II RNase protection assay in cultured SK-N-SH and SH-SY5Y neuroblastoma cells. An 854 bp IGF II cDNA obtained from human liver was used as the template for riboprobe synthesis. RNA from cultured human retinal pigment epithelial cells did not protect this probe, whereas RNA from both SK-N-SH and SH-SY5Y cells protected a $580 \mathrm{bp}$ fragment. Radiograph exposed $48 \mathrm{~h}$. 

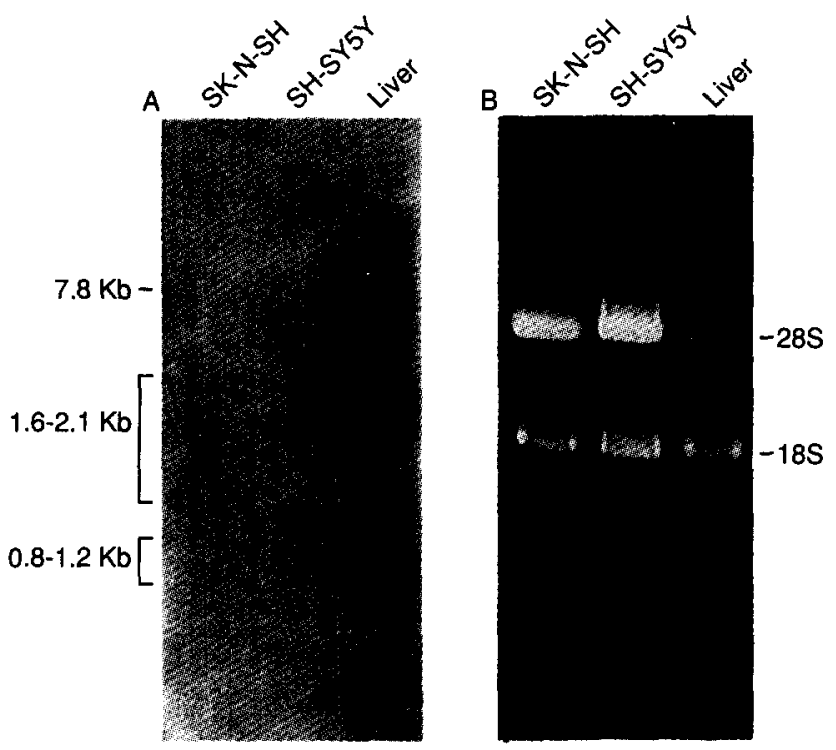

Fig. 2. Northern analysis of IGF I in cultured human neuroblastoma cells. A: Northern blot of $20 \mu \mathrm{g}$ total RNA from SK-N-SH and SH-SY5Y neuroblastoma cells. No RNA transcripts were detected in either neuroblastoma cell line, whereas the expected RNA transcript sizes were seen in rat liver total RNA. Radiograph exposed 3 days. B: photograph of ethidium bromide-stained gel corresponding to the membrane used in $\mathrm{A}$, showing $28 \mathrm{~S}(5.0 \mathrm{~kb})$ and $18 \mathrm{~S}(1.8 \mathrm{~kb})$ rRNA bands.

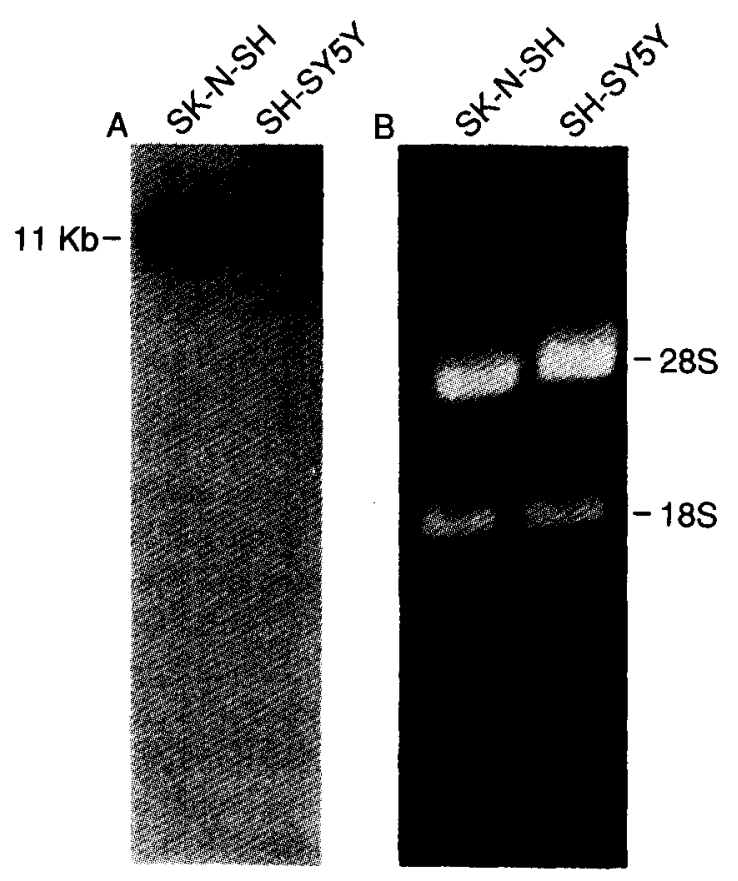

Fig. 3. Northern analysis of type I IGF receptor in cultured human neuroblastoma cells. A: Northern blot of $20 \mu \mathrm{g}$ total RNA from SK-N-SH and SH-SY5Y neuroblastoma cells. One $11 \mathrm{~kb}$ RNA transcript was detected in both neuroblastoma cell lines. Radiograph exposed 3 days. B: photograph of ethidium bromide-stained gel corresponding to the membrane used in $\mathrm{A}$, showing $28 \mathrm{~S}(5.0 \mathrm{~kb})$ and $18 \mathrm{~S}(1.8 \mathrm{~kb})$ rRNA bands.



Fig. 4. Northern analysis of type II IGF receptor in cultured human neuroblastoma cells. A: Northern blot of $20 \mu \mathrm{g}$ total RNA from SK-N-SH and SH-SY5Y neuroblastoma cells. One $9.4 \mathrm{~kb}$ RNA transcript was detected in both neuroblastoma cell lines. Radiograph exposed 5 days. B: photograph of ethidium bromide-stained gel corresponding to the membrane used in $\mathrm{A}$, showing $28 \mathrm{~S}(5.0 \mathrm{~kb})$ and $18 \mathrm{~S}(1.8 \mathrm{~kb})$ rRNA bands.

RNase protection analysis of total RNA from both cell lines, we found a $580 \mathrm{bp}$ fragment of the 854-bp IGF II probe was protected from RNase degradation. (Fig. 1C). No specific hybridization between the 818 bp IGF I cDNA and total RNA from SH-SY5Y or SK-N-SH cells in Northern analysis experiments was detected (Fig. 2A,B). In the same experiments, we detected multiple IGF I mRNA transcripts of 7.8, 1.6-2.1, and $0.8-1.2 \mathrm{~kb}$ by Northern hybridization of the $818 \mathrm{bp}$ IGF I cDNA with rat liver total RNA (Fig. 2A,B). This result is consistent with previously reported IGF I transcript sizes in rat liver ${ }^{34}$.

\section{IGF receptor gene expression}

By Northern analysis with the 1247 bp type I IGF receptor cDNA of total RNA from SH-SY5Y or SK-N$\mathrm{SH}$ cells, we detected one $11 \mathrm{~kb}$ RNA transcript (Fig. 3A,B). Using Northern analysis with the $9.1 \mathrm{~kb}$ type II IGF receptor cDNA, we detected one $9.4 \mathrm{~kb}$ RNA transcript in total RNA from SH-SY5Y and SK-N-SH cells (Fig. 4A,B).

\section{DISCUSSION}

Multiple class sizes of IGF I and IGF II mRNAs are expressed in a tissue and time specific manner. In 
human fetal brain, the major IGF I mRNA species are 7.5 and $4.4 \mathrm{~kb}$, while 1.6 and $2.5 \mathrm{~kb}$ IGF I mRNA transcripts are present in the adult ${ }^{31}$. Transcription of the human IGF II gene is under the control of multiple promoters $^{13}$. In human fetal tissue, the P3 promoter is active, giving rise to abundant $6.0 \mathrm{~kb}$ IGF II mRNAs. Initiation of transcription of the $\mathrm{P} 4$ promoter predominates in the adult, producing lower total amounts of IGF II mRNA and a major $4.8 \mathrm{~kb}$ transcript ${ }^{5.6}$.

The developmentally specific expression of multiple IGF mRNA species in the nervous system implies a role for IGFs in neuronal growth and maturation. We have used two neuroblastoma cell lines, SK-N-SH and SH-SY5Y, as models of neuronal development. Each cell line can undergo active neuronal division and neurite outgrowth in response to IGFs ${ }^{12,21,26,27,28}$. Similar phenotypic changes occur in vivo in developing neurons, leading us to speculate that these neuroblastoma cells would express fetal IGF transcripts.

Using RNase protection assays, we detected IGF II mRNA in SH-SY5Y cells and, in concurrence with Yee and colleagues ${ }^{37}$, in SK-N-SH cells. Northern analysis of both cell types revealed three IGF II mRNA transcripts: $6.0 \mathrm{~kb}, 4.8 \mathrm{~kb}$ and $1.8 \mathrm{~kb}$. The predominant IGF II mRNA in both cell lines was the $6.0 \mathrm{~kb}$ transcript, the major IGF II species in human fetal tissues ${ }^{5.6}$. High levels of the $6.0 \mathrm{~kb}$ IGF II transcript in both neuroblastoma cell lines therefore mimics human fetal development.

In adult human, a sharp decline in total IGF II mRNA transcript levels coincides with the increased presence of the $4.8 \mathrm{~kb}$ IGF II transcript ${ }^{5,6,33}$. Correspondingly, we found low levels of the $4.8 \mathrm{~kb}$ mRNA, presumably under the control of the $\mathrm{P} 4$ promoter, in actively growing SK-N-SH and SH-SY5Y cells. The third transcript, the $1.8 \mathrm{~kb}$ IGF II mRNA, was present in low amounts in both SK-N-SH and SH-SY5Y cells. While the exact significance of this transcript remains unclear, increasing evidence suggests it is the cleavage product of larger IGF II mRNAs and functions to regulate total IGF II mRNA levels ${ }^{35}$.

Little is known about the potential developmental regulation of type I and II IGF receptor gene expression. The type I IGF receptor is a membrane glycoprotein with four subunits connected by disulfide bonds to give a $\beta-\alpha-\alpha-\beta$ tetramer. IGF I binds to the $\alpha$ subunits and stimulates autophosphorylation of the $\beta$ subunits via a tyrosine-specific protein kinase ${ }^{18}$. In multiple tissues, IGF I cDNA hybridization reveals an $11 \mathrm{~kb}$ and/or a $7 \mathrm{~kb}$ transcript ${ }^{36}$. We detected the $11 \mathrm{~kb}$ type l IGF receptor transcript in both actively growing neuroblastoma cell lines, in agreement with previous RNase protection assays ${ }^{22,37}$. Competitive binding and
RNase protection assays indicate increased type I IGF receptor binding and mRNA levels after differentiation of SH-SY5Y cells ${ }^{22}$, however, the potential changes in type I IGF receptor transcript species are unknown. Interestingly, when mouse 3T3-L1 fibroblasts are differentiated into adipocytes, there is a reduction of the type I IGF receptor $11 \mathrm{~kb}$ transcript ${ }^{36}$.

Unlike the type I IGF receptor, the type II IGF receptor is a single polypeptide with no intrinsic tyrosine kinase activity. The type II IGF receptor is identical to the mannose-6-phosphate receptor ${ }^{19}$, which mediates intracellular trafficking of lysosomal enzymes ${ }^{4}$. The physiological significance of one receptor with distinct ${ }^{2}$ but cooperative bindings sites for IGF II and mannose-6-phosphate ${ }^{29}$ is unknown. Recent work, however, suggests that the type II IGF receptor may serve to integrate distinct growth-promoting signals from IGF II and mannose-6-phosphate ${ }^{7}$ or secreted mannose-6-phosphate containing proteins, including cathepsin $\mathrm{D}^{17}$, proliferin ${ }^{14}$ and transforming growth factor- $\beta 1$ precursor $^{25}$. The presence of type II IGF receptor mRNA has not been previously reported in neuroblastoma cell lines. We detected a $9.4 \mathrm{~kb}$ transcript in actively growing SH-SY5Y and SK-N-SH cells, the same size as the type II IGF receptor transcript in human placenta ${ }^{20}$. There is little information on the potential regulation of type II IGF receptor gene expression with development, although competitive binding studies with iodinated-IGFs indicate changes in IGF receptor subtypes during fetal maturation ${ }^{32}$.

We were unable to detect IGF I mRNA in either SK-N-SH or SH-SY5Y cells, in agreement with Yee and colleagues ${ }^{37}$. We believe this increases the utility of these two cell lines as models of neuronal development. The lack of IGF I gene expression will allow us to examine the effects of IGF II on neuronal growth and differentiation separately from IGF I.

Examined collectively, the presence of (1) abundant $6.0 \mathrm{~kb}$ IGF II mRNA with low abundance of 4.8 and $1.8 \mathrm{~kb}$ IGF II mRNAs, and (2) abundant $11.0 \mathrm{~kb}$ type I and $9.4 \mathrm{~kb}$ type II IGF receptor mRNA in dividing SK-N-SH and SH-SY5Y cells supports our contention that these cell lines are useful for understanding the differential regulation of IGF and IGF receptor mRNA during neuronal development. As an initial step toward determining the role of IGFs in neuronal ontogeny, we have begun examining changes in IGF II gene expression in differentiated neuroblastoma cell lines ${ }^{15}$.

Acknowledgements. We wish to thank Dr. Patrick Venta and Ann Randolph for assistance with experimental design. We also thank Naive Wong for technical assistance. We are grateful to Dr. Peter Rotwein for providing the IGF I cDNA, Dr. Graeme Bell for the IGF II cDNA, Dr. Axel Ullrich for the type I IGF receptor cDNA 
and Dr. William S. Sly for the type II IGF receptor cDNA. Funding for D.M.M. is from NIH Training Grant NS 07222-09. D.Y. is a Pew Scholar in the Biomedical Sciences and is supported by Grant R29 CA52592. R.O.C. is supported by NIMH Biological Sciences Research Training Grant MH-15794. E.L.F. is supported by NIH Grant NS01380.

\section{REFERENCES}

1 Bell, G.I., Merryweather, J.P., Sanchez-Pescador, R., Stempien, M.M., Priestley, L., Scott, J. and Rall, L.B., Sequence of a cDNA clone encoding human preproinsulin-like growth factor II, $\mathrm{Na}$ ture, 310 (1984) 775-777.

2 Braulke, T., Causin, C., Waheed, A., Junghans, U., Hasilik, A., Maly P., Humbel, R.E. and von Figura, K., Mannose-6-phosphate/insulin-like growth factor II receptor: distinct binding sites for mannose 6-phosphate and insulin-like growth factor II, Biochem. Biophys. Res. Commun., 150 (1988) 1287-1293.

3 Chomczynski, P. and Sacchi, N., Single-step method of RNA isolation by acid guanidinium thiocyanate-phenol-chloroform extraction, Anal. Biochem., 162 (1987) 156-159.

4 Dahms, N.M., Lobel, P. and Kornfeld, S., Mannose 6-phosphate receptors and lysosomal enzyme targeting, J. Biol. Chem., 264 (1989) 12115-12118.

5 de Pagter-Holthuizen, P., Jansen, M., van Schaik, F.M.A., van der Kammen, R., Oosterwijk, C., Van den Brande, J.L. and Sussenbach, J.S., The human insulin-like growth factor II gene contains two development-specific promoters, FEBS Lett., 214 (1987) 259-264.

6 de Pagter-Holthuizen, P., Jansen, M., van der Kammen, R.A., van Schaik, F.M.A. and Sussenbach, J.S., Differential expression of the human insulin-like growth factor II gene. Characterization of the IGF-II mRNAs and an mRNA encoding a putative IGFII-associated protein, Biochem. Biophys. Acta, 950 (1988) 282-295.

7 Feldman, E.L. and Randolph, A.E., Mannose 6-phosphate potentiates insulin-like growth factor II effects in cultured human neuroblastoma cells, Brain Res., 562 (1991) 111-116.

8 Hepler, J.E. and Lund, P.K., Molecular biology of the insulin-like growth factors. Relevance to nervous system function, $\mathrm{Mol}$. Neurobiol., 4 (1990) 93-127.

9 Hoyt, E.C., Van Wyk, J.J. and Lund, P.K., Tissue and development specific regulation of a complex family of rat insulin-like growth factor I messenger ribonucleic acids, Mol. Endocrinol., 2 (1988) $1077-1086$.

10 Humbel, R.E., Insulin-like growth factors I and II, Eur. J. Biochem., 190 (1990) 445-462.

11 Irminger, J.C., Rosen, K.M., Humbel, R.E. and Villa-Komaroff, L., Tissue-specific expression of insulin-like growth factor II mRNAs with distinct $5^{\prime}$ untranslated regions, Proc. Natl. Acad. Sci. USA, 84 (1987) 6330-6334.

12 Ishii, D.N. and Recio-Pinto, E., Role of insulin, insulin like growth factors, and nerve growth factor in neurite formation. In M.K. Raizada, M.I. Phillips D. LeRoith (Eds.), Insulin, InsulinLike Growth Factors, and Their Receptors in the Central Nervous System, Plenum, New York, 1987, pp. 315-348.

13 Jansen, M., Holthuizen, P., van Dijk, M.A., van Schaik, F.M.A., Van de Brande, J.L. and Sussenbach, J.S., Structure and expression of the insulin-like growth factor II (IGF-II) gene. In V.R. Sara et al. (Eds.), Growth Factors: From Genes to Clinical Application, Raven, New York, 1990, pp. 25-40.

14 Lee S.-J. and Nathans, D., Proliferin secreted by cultured cells binds to mannose 6-phosphate receptors, J. Biol. Chem., 263 (1988) 3521-3527.

15 Martin, D.M., Carlson, R.O., Feldman, E.L., Regulation of IGF-II gene expression during neuroblastoma proliferation and differentiation, Soc. Neurosci. Abstr., 17 (1991) 448.6.

16 Martin, D.M., Yee, D. and Feldman, E.L., Gene expression of the insulin-like growth factors and their receptors in cultured human retinal pigment epithelial cells, Mol. Brain Res., 12 (1991) 181-186.

17 Mathieu, M., Rochefort, H., Barenton, B., Prebois, C. and Vi- gnon, F., Interactions of cathepsin-D and insulin-like growth factor-II (IGF-II) on the IGF-II/mannose-6-phosphate receptor in human breast cancer cells and possible consequences on mitogenic activity of IGF-1I, Mol. Endocrinol., 4 (1990) 1327-1335.

18 Morgan, D.O., Jarnagin, K. and Roth, R.A., Purification and characterization of the receptor for insulin-like growth factor $\mathrm{I}$, Biochemistry, 25 (1986) 5560-5564.

19 Morgan, D.O., Edman, J.C., Standring, D.N., Fried, V.A., Smith, M.C., Roth, R.A. and Rutter, W.J., Insulin-like growth factor II receptor as a multifunctional binding protein, Nature, 329 (1987) 301-307.

20 Oshima, A., Nolan, C.M., Kyle, J.W., Grubb, J.H. and Sly, W.S., The human cation-independent mannose 6-phosphate receptor, J. Biol. Chem., 263 (1986) 2553-2562.

21 Ota, A., Wilson, G.L., Spilberg, O., Pruss, R. and LeRoith, D., Functional insulin-like growth factor I receptors are expressed by neural-derived continuous cell lines, Endocrinology, 122 (1988) $145-152$.

22 Ota, A., Shen-Orr, Z., Roberts, C.T. Jr., LeRoith, D., TPA-induced neurite formation in a neuroblastoma cell line (SH-SY5Y) is associated with increased IGF-I receptor mRNA and binding, Mol. Brain Res., 6 (1989) 69-76.

23 Påhlman, S., Odelstad, L., Larsson, E., Grotte, G. and Nillson K., Phenotypic changes of human neuroblastoma cells in culture induced by $12-O$-tetradecanoyl-phorbol-13-acetate, Int. J. Cancer, 28 (1981) 583-589.

24 Påhlman, S., Mamaeva, S., Meyerson, G., Mattson, M.E.K., Bjelfman, C., Örtoft, E. and Hammerling, U., Human neuroblastoma cells in culture: a model for neuronal cell differentiation and function, Acta Physiol. Scand., Suppl. 592 (1990) 25-37.

25 Purchio, A.F., Cooper, J.A., Brunner, A.M., Lioubin, M.N., Gentry, L.E., Kovacina, K.S., Roth, R.A. and Marquardt, H., Identification of mannose-6-phosphate in two asparagine-linked sugar chains of recombinant transforming growth factor- $\beta 1$ precursor, J. Biol. Chem., 263 (1988) 14211-14215.

26 Recio-Pinto, E. and Ishii, D.N., Effects of insulin, insulin-like growth factor-II and nerve growth factor on neurite outgrowth in cultured human neuroblastoma cells, Brain Res., 302 (1984) 323334.

27 Recio-Pinto, E., Lang, F.F. and Ishii, D.N., Insulin and insulin-like growth factor II permit nerve growth factor binding and the neurite formation response in cultured human neuroblastoma cells, Proc. Natl. Acad. Sci. USA, 81 (1984) 2562-2566.

28 Recio-Pinto, E. and Ishii, D.N., Insulin and insulin like growth factor receptors regulating neurite formation in cultured human neuroblastoma cells, J. Neurosci. Res., 19 (1988) 312-320.

29 Roth, R.A., Stover, C., Hari, J., Morgan, D.O., Smith, M.C., Sara, V. and Fried, V.A., Interactions of the receptor for insulinlike growth factor II with mannose-6-phosphate and antibodies to the mannose-6-phosphate receptor, Biochem. Biophys. Res. Commun., 149 (1987) 600-606.

30 Rotwein, P., Folz, R.J. and Gordon, J.I., Biosynthesis of human insulin-like growth factor I (IGF-I), J. Biol. Chem., 262 (1987) 11807-11812.

31 Sandberg A-C., Engberg, C., Lake, M., von Holst, H. and Sara, V.R., The expression of insulin-like growth factor $I$ and insulinlike growth factor II genes in the human fetal and adult brain and in glioma, Neurosci. Lett., 93 (1988) 114-119.

32 Sara, V.R., Hall, K., Misaki, M., Fryklund, L., Christensen, N. and Wetterberg, L., Ontogenesis of somatomedin and insulin receptors in the human fetus, J. Clin. Invest., 71 (1983) 1084-1094.

33 Sara, V.R. and Hall, K., Insulin-like growth factors and their binding proteins, Physiol. Rev., 70 (1990) 591-614.

34 Shimatsu, A. and Rotwein, P., Mosaic evolution of the insulin-like growth factors, J. Biol. Chem., 262 (1987) 7894-7900.

35 Sussenbach, J.S., Steenbergh, P.H., Jansen, E., Meinsma, D., van Dijk, M.A., Holthuizen, P., de Moor, C.H., Jansen, M. and Van den Brande, J.L., Structure and post-transcriptional regulation of expression of the human IGF-I and -II genes. In E.M. Spencer (Ed.), Modern Concepts of Insulin-Like Growth Factors, Elsevier, New York, 1991, pp. 639-654.

36 Ullrich, A., Gray, A., Tam, A.W., Yang-Feng, T., Tsubokawa, M., 
Collins, C., Henzel, W., Le Bon, T., Kathuria, S., Chen, E., Jacobs, S., Francke U., Ramachandran, J. and Fujita-Yamaguchi, Y., Insulin-like growth factor I receptor primary structure: comparison with insulin receptor suggests structural determinants that define functional specificity, EMBO J., 5 (1986) 2503-2512.
37 Yee, D., Favoni, R.E., Lebovic, G.S., Lombana, F., Powell, D.R., Reynolds, C.P. and Rosen, N., Insulin-like growth factor I expression by tumors of neuroectodermal origin with the $t(11 ; 22)$ chromosomal translocation: a potential autocrine growth factor, $J$. Clin. Invest., 86 (1990) 1806-1814. 